\title{
BREEDING FOR ORGANIC FARMING: OBTAINING AND EVALUATION OF FLAX SOMACLONAL FAMILIES
}

\section{Andra Mikelsone ${ }^{1 ; 2}$, Dace Grauda ${ }^{1}$, Veneranda Stramkale ${ }^{3}$, Isaak Rashal ${ }^{1}$}

1- Institute of Biology, University of Latvia

Miera Street 3, Salaspils, Latvia; ph.: +37167945435, e-mail: andra@email.lubi.edu.lv; dace@email.lubi.edu.lv; izaks@email.lubi.edu.lv

2- Daugavpils University

Vienības Street 13, Daugavpils, Latvia

3- Agricultural Science Centre of Latgale, Kultūras sq. 1, Viḷāni, Viḷānu distr., Latvia

Ph.: +371 29465044, e-mail: strzin@ apollo.lv

\begin{abstract}
Plant calli culture could be used as a source of genetic changes (somaclonal variation). There are known several flax varieties, bred on the basis of somaclonal variation, with improved resistance to biotic and abiotic stresses, plant height, seed yield and other traits. This method is useful for obtaining the new initial material for flax breeding, including for intensification of breeding for organic farming. Goal of the study was to obtain plants-regenerants from the calli culture of the fibre flax variety 'Vega 2' and to evaluate their agronomical traits and resistance to powdery mildew. For obtaining plants-regenerants was used early elaborated protocol of somatic calli cultivation. Agronomically important traits, such as total and technical plant height, number of seed vessels, number of seeds in a seed vessel, and resistance to diseases were evaluated. Most of somaclonal families had higher total and technical plant height in comparison with the initial variety 'Vega 2'. In the opposite, number of seed vessels and number of seeds in a seed vessel had a tendency to decrease. It was concluded that even changes in not desirable direction may be recognised as an indirect indicator of the rather high level of induced somaclonal variation, which can occurred also in traits, which were not evaluated during this experiment, therefore there is a potential to exploit flax somaclonal variation in applied breeding programs as an additional source of variability.
\end{abstract}

Keywords: fibre flax, calli culture, somaclonal variation, agronomical traits.

\section{Introduction}

Processing and use of different types of renewable resources is an actual task for future development of industry. Among them are different crops, adapted for growing in appropriate territories. Flax, from this point of view, is very promising cultivated plant because it can be used for producing of wide choice goods and products. From the one hand, flax seeds contain up to $40 \%$ of oil, and are very riche source of polyunsaturated fatty acids, vitamins, proteins, muciloginous substances and antioxidants. Thanks this fact flax oil is used broadly in medicine and modern pharmacology. Flax seeds are used as well as a source of industrial oil in the production of paints, varnishes, inks, linoleum etc. From the other hand, flax fibre and shove can be used in textile industry, as engineering and building material, and as well as the energy resource [1]. Exclusive new flax niche products with high added value could be produced by organic farming.

For obtaining of high-quality yield the choice of appropriate varieties is crucial. Unfortunately, presently there are not officially registered and recommended for growing any local flax varieties suitable for the Latvian weather conditions. Therefore an important task for the Latvian flax breeding is obtaining high yielding, middle early varieties with the good resistance to logging and to flax diseases, which could be suitable both for conventional and organic farming. For obtaining a good yield in conditions of organic farming especially important is variety resistance to biotic and abiotic stresses. Breeding of flax even nowadays is a long and complicated process, based on hybridization and selection of the best plants. Taking in account the facultative cross-pollination, the development of genetically stabile lines could take more than 15 years $[2,3]$. 
For intensification of the breeding process we are looking for a possibility to use methods of biotechnology, for example, somatic calli culture, to obtain additional flax breeding initial material without necessity of crossing of different parent genotypes. It is well known that plants- regenerants from calli culture often perform higher variation, so called somaclonal variation. Somaclonal variation has been described for many crops, including flax. Three types of the variation are described: heritable stable, heritable unstable and non-heritable (epigenetic) [4-6].

From practical point of view it is important that many changes occur in agronomic traits, for example in disease resistance, dates of heading and maturation, plant height, seed yield and quality etc. [7-10]. However, the possibility to select and use somaclonal variants in breeding is different for specific traits and is considerably depended from the genotype of particular variety. By explore of somaclonal variation, new flax lines have been derived with increasing resistance to biotic and abiotic stress, plant height, number of seeds in a vessel, and number of seeds [11-13]. The goal of the study was to obtain plants-regenerants from the calli culture of the commercially registered in Latvia fibre flax variety 'Vega 2', bred in Lithuania, and to evaluate their agronomical traits and resistance to powdery mildew.

Obtaining of somaclonal families

\section{Materials and methods}

For calli induction explants (stem segments) of the variety 'Vega 2' were placed on the Murashige and Skoog (MS) medium with 2,4-dichlorophenoxyacetic acid (2,4-D, $1.0 \mathrm{mg} / \mathrm{l})$. As a calli regeneration medium was used MS medium with 6-benzylamiopurine (BAP, 1.0 $\mathrm{mg} / \mathrm{l}$ ), for induction of shoot formation MS medium with addition of indolil acetic acid (IAA, $0.1 \mathrm{mg} / \mathrm{l}$ ) was used. Shoots of regenerants with the length $3-6 \mathrm{~cm}$ have been cut 2-4 times and rooted. Plantlets with roots about $0.5 \mathrm{~cm}$ were planted in the autoclaved sand fertilized by 0.5 MS medium salts. Well rooted plants were transferred from the sand into soil and covered by a glass [14]. 30 plants-regenerants from the one calli were chosen for evolution of somaclonal variation. Progenies of the each 30 plants-regenerants comprise a separate somaclonal family.

\section{Field experiments}

Somaclonal families were evaluated in field trial in the Agricultural Science Centre of Latgale in 2010. Somaclonal families were grown in 2-3 rows (depending of the number of available seeds) plots, between the plots a long straw oat variety was sown. Agriculturally important traits, such as flax total plant height, technical plant height, number of seed vessels and number of seeds in a seed vessel were evaluated. Somaclonal families were compared with the source variety 'Vega 2'.

\section{Detection of resistance to powdery mildew}

Resistance of 20 seedlings of the each somaclonal family to powdery mildew was detected in greenhouse in September 2010 when highest level of fungi spores was occurred. Resistance were recorded on the age started from 5 till 9 weeks in the scale 0 (fully resistant) -4 (completely susceptible).

$\underline{\text { Data analysis }}$

Microsoft Excel program was used for data statistical processing. Phenotypical correlation coefficients were calculated among individual data of all plants of the experiment, genotypical correlation coefficients were calculated as correlations among mean values of corresponding traits of somaclonal families, environmental correlation coefficients were calculated separately among individual plant characteristics within each somaclonal family. 


\section{Results and discussion}

The total plant height and technical plant height of flax somaclonal families and the source fibre flax variety 'Vega 2' are presented on Fig. 1. Somaclonal families shown considerable variation in this trait, most of them were higher than 'Vega 2'. The similar situation was observed in the plant technical height which was demonstrated previously [3] as the most important trait for the fibre flax breeding. Obtained somaclonal families could be used in breeding as an additional initial material for the fibre flax breeding.

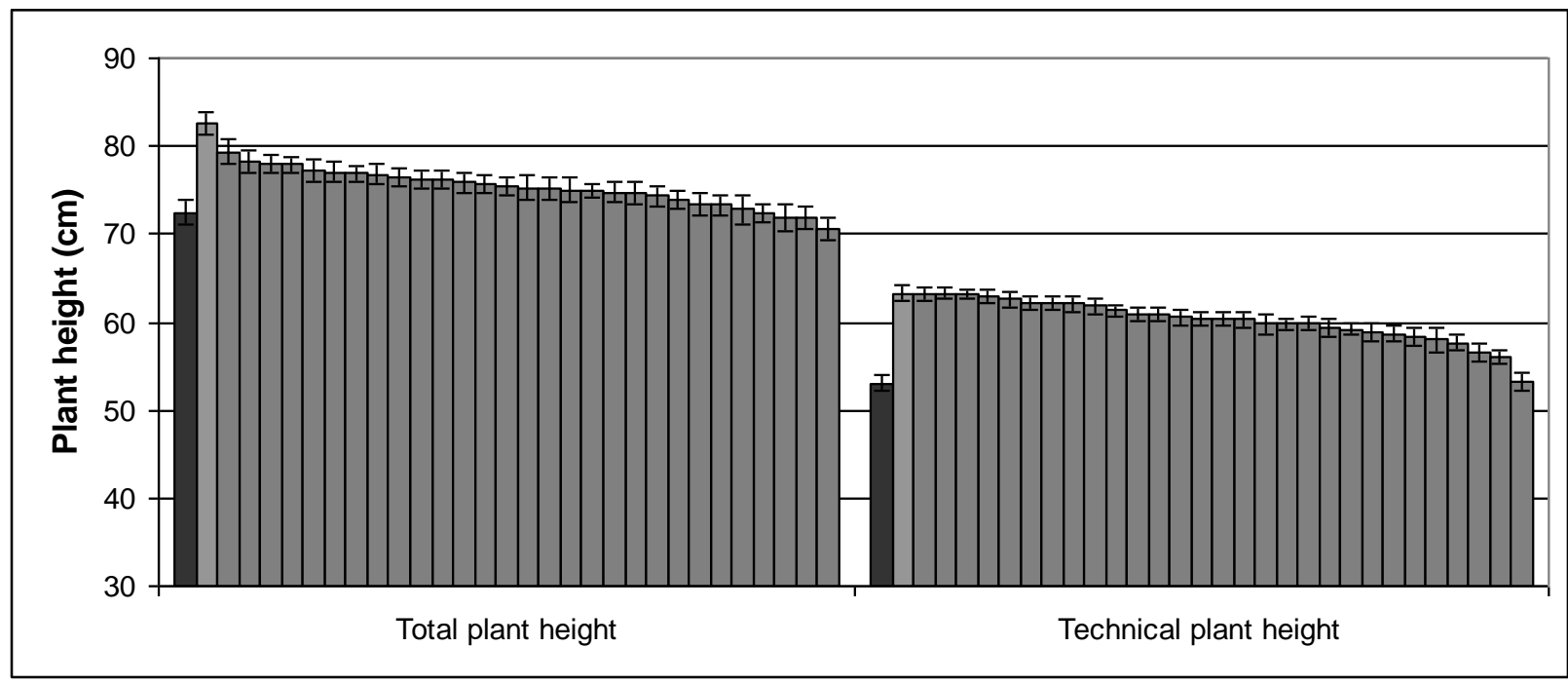

Fig.1. Total plant height and technical plant height of flax somaclonal families and source variety 'Vega 2' (black column)

Number of seed vessels (Fig. 2) showed a tendency to decrease in comparison with the source variety 'Vega 2', several somaclonal families had substantially reduced number of seed vessels. All somaclonal families have less seeds in a seed vessel than source variety 'Vega 2'. These changes are not desirable to breeding.

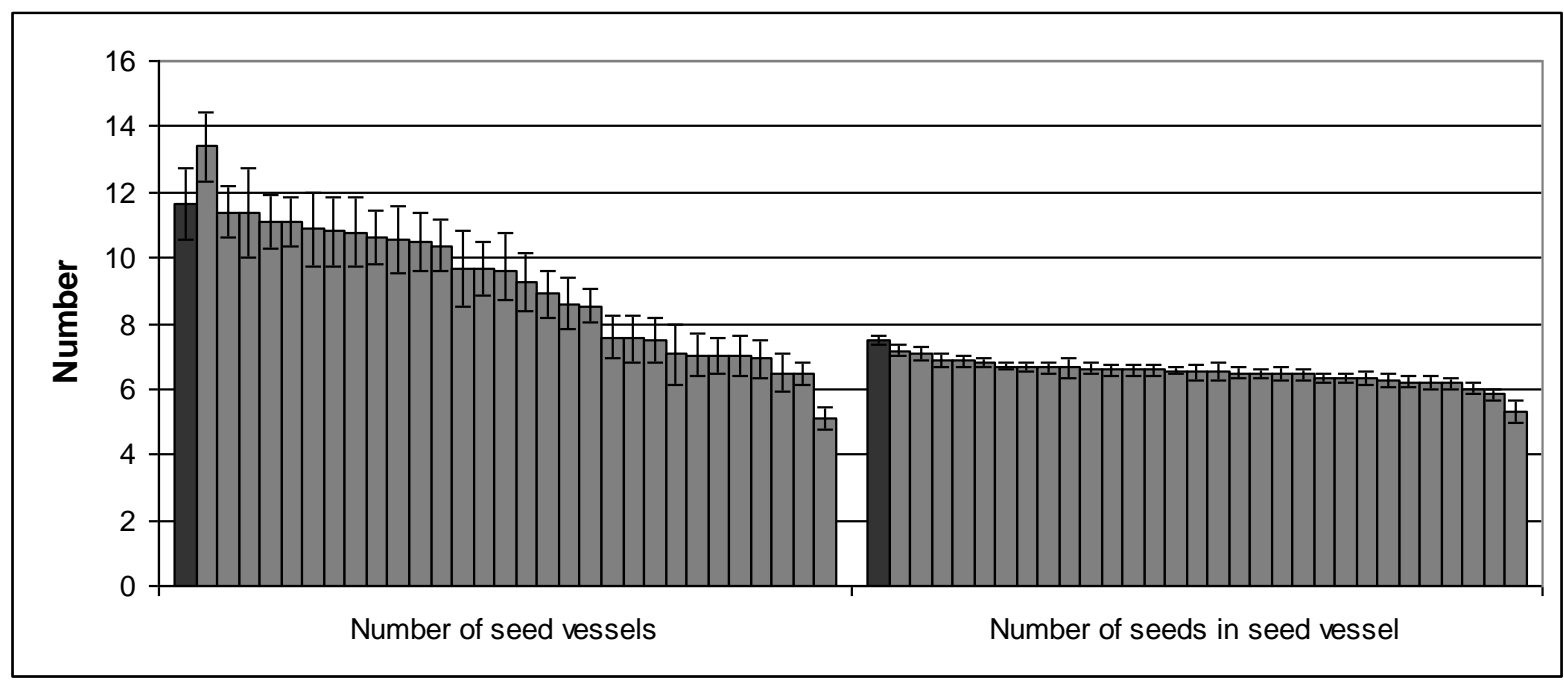

Fig.2. Number of seed vessels and number of seeds in a seed vessel of flax somaclonal families and source variety 'Vega 2' (black column)

In the Table 1 are presented phenotypical and genotypical correlation coefficients between evaluated flax traits. As expected, there are high both phenotypical and genotypical correlations among close related total plant height and technical plant height, what showing, 
that preliminary selection for technical plant height could be done on the base of evaluation of total plant height. In opposite, there was observed not favourable for breeding significant negative correlation among technical plant height and number of seed vessels while the correlation between those traits on phenotypic level was absent. Most of other correlations were not significant.

Table 1.

Phenotypical (above diagonal) and genotypical (below diagonal) correlation coefficients among traits of flax somaclonal families

\begin{tabular}{|c|c|c|c|c|}
\hline & $\begin{array}{c}\text { Total plant } \\
\text { height }\end{array}$ & $\begin{array}{c}\text { Technical plant } \\
\text { height }\end{array}$ & $\begin{array}{c}\text { Number of seed } \\
\text { vessels }\end{array}$ & $\begin{array}{c}\text { Number of } \\
\text { seeds in a seed } \\
\text { vessel }\end{array}$ \\
\hline $\begin{array}{c}\text { Total plant } \\
\text { height }\end{array}$ & - & $0,6123^{* *}$ & $0,5840^{* *}$ & 0,1035 \\
\hline $\begin{array}{c}\text { Technical plant } \\
\text { height }\end{array}$ & $0,5851^{* *}$ & - & $-0,0122$ & $-0,0455$ \\
\hline $\begin{array}{c}\text { Number of seed } \\
\text { vessels }\end{array}$ & 0,2985 & $-0,5046^{* *}$ & - & 0,1283 \\
\hline $\begin{array}{c}\text { Number of } \\
\text { seeds in a seed } \\
\text { vessel }\end{array}$ & 0,0691 & $-0,2334$ & $0,4764 * *$ & - \\
\hline
\end{tabular}

** - correlation significant at $\mathrm{p} \leq 0.01$

Coefficients of environmental correlation are presented in the Table 2. Those correlations could not be used directly for breeding purpose because based on not heritable trait variation but differences between environmental correlations among families pointed out on they different reaction norm (in other term, genotype and environment interaction) as a consequence of somaclonal variation. For example, plants of several families had not correlation between total and technical plant height, there was big variation among families in correlation between total and technical plant height and seed vessels characteristics.

Variety 'Vega-2' was fully resistant to powdery mildew. Nevertheless, that not any somaclonal family was completely susceptible, only $50 \%$ of somaclonal families retained highest level of resistance of the initial variety (Table 3 ).

Somaclonal variation occurred in this experiment was positive, and, as well, negative from breeding point of view. As it is known, somaclonal variation is usually asymmetric and changes in most cases are occurred in direction not desirable for breeding. Nevertheless, the big number of families with decreased seed production and lower level of resistance may be recognised as an indirect indicator of the rather high level of induced somaclonal variation. which could influence also other traits which were not evaluated in this investigation.

\section{Conclusions}

Considerable somaclonal variation in agronomic important traits include technical plant height has been demonstrated among plants regenerated from stem calli culture of fibre flax variety 'Vega 2'. Because increased variation, lines with favourable combinations of agronomically important traits for fibre flax growing in the Latvian conditions, including organic farming, could be selected from obtained somaclonal families in further breeding process. In general, there is a potential to exploit flax somaclonal variation in applied breeding programs as an additional source of variability. 
Table 2.

Coefficients of environmental correlations among traits within flax somaclonal families

\begin{tabular}{|c|c|c|c|c|c|c|}
\hline $\begin{array}{c}\text { Somaclonal } \\
\text { family }\end{array}$ & $\begin{array}{c}\text { Total plant } \\
\text { height / } \\
\text { technical } \\
\text { plant } \\
\text { height }\end{array}$ & $\begin{array}{l}\text { Total plant } \\
\text { height / } \\
\text { number of } \\
\text { seed } \\
\text { vessels }\end{array}$ & $\begin{array}{c}\text { Technical } \\
\text { plant } \\
\text { height / } \\
\text { number } \\
\text { of seed } \\
\text { vessels }\end{array}$ & $\begin{array}{c}\text { Total } \\
\text { plant } \\
\text { height / } \\
\text { number } \\
\text { of seeds } \\
\text { in a seed } \\
\text { vessel }\end{array}$ & $\begin{array}{c}\text { Technical } \\
\text { plant } \\
\text { height / } \\
\text { number } \\
\text { of seeds } \\
\text { in a seed } \\
\text { vessel }\end{array}$ & $\begin{array}{c}\text { Number } \\
\text { of seed } \\
\text { vessels / } \\
\text { number } \\
\text { of seeds } \\
\text { in a seed } \\
\text { vessel }\end{array}$ \\
\hline 'Vega 2' & $0,719 * *$ & $0,863 * *$ & $0,408^{*}$ & 0,345 & $0,439 *$ & 0,340 \\
\hline 7LSm1 & $0,693 * *$ & 0,290 & 0,055 & $-0,265$ & $-0,188$ & $-0,114$ \\
\hline 7LSm2 & $0,710 * *$ & $0,627 * *$ & 0,039 & $0,406^{*}$ & 0,207 & 0,359 \\
\hline 7LSm3 & $0,559 * *$ & $0,737 * *$ & $-0,006$ & 0,092 & 0,190 & $-0,082$ \\
\hline 7LSm4 & 0,257 & $0,790 * *$ & $-0,163$ & $-0,047$ & $-0,223$ & 0,090 \\
\hline 7LSm5 & 0,287 & $0,741 * *$ & $-0,330$ & $0,471 * *$ & 0,108 & 0,350 \\
\hline 7LSm6 & $0,674 * *$ & $0,648 * *$ & $-0,075$ & 0,310 & 0,239 & 0,083 \\
\hline 7LSm7 & $0,610 * *$ & $0,802 * *$ & 0,295 & 0,042 & $-0,179$ & 0,155 \\
\hline 7LSm8 & $0,626^{* *}$ & $0,608 * *$ & $-0,092$ & 0,308 & 0,200 & 0,333 \\
\hline 7LSm9 & $0,652 * *$ & $0,614 * *$ & 0,067 & 0,354 & 0,183 & 0,199 \\
\hline 7LSm10 & $0,456 * *$ & $0,619 * *$ & $-0,192$ & 0,151 & $-0,465 * *$ & $0,406^{*}$ \\
\hline 7LSm11 & $0,625 * *$ & $0,758 * *$ & 0,132 & 0,169 & $-0,239$ & $0,386^{*}$ \\
\hline 7LSm12 & $0,862 * *$ & $0,714^{* *}$ & $0,406^{*}$ & $-0,381^{*}$ & $-0,330$ & $-0,401^{*}$ \\
\hline 7LSm13 & $0,699 * *$ & $0,546 * *$ & 0,053 & 0,400 & 0,328 & 0,349 \\
\hline 7LSm14 & $0,725^{* *}$ & $0,605 * *$ & 0,010 & 0,023 & 0,066 & $-0,229$ \\
\hline 7LSm15 & $0,651 * *$ & $0,881 * *$ & $0,527 * *$ & $-0,003$ & $-0,082$ & $-0,090$ \\
\hline 7LSm16 & $0,669 * *$ & $0,805 * *$ & 0,285 & $-0,365^{*}$ & $-0,307$ & $-0,337$ \\
\hline 7LSm17 & $0,738 * *$ & $0,785^{* *}$ & 0,336 & 0,341 & 0,105 & $0,402^{*}$ \\
\hline 7LSm18 & $0,805^{* *}$ & $0,719 * *$ & 0,256 & 0,040 & 0,122 & $-0,214$ \\
\hline 7LSm19 & $0,910 * *$ & $0,872 * *$ & $0,658 * *$ & 0,173 & 0,188 & 0,303 \\
\hline 7LSm20 & $0,795 * *$ & $0,791 * *$ & 0,308 & 0,177 & 0,026 & 0,269 \\
\hline 7LSm21 & 0,122 & $0,795 * *$ & $-0,234$ & 0,088 & $-0,313$ & 0,153 \\
\hline 7LSm22 & $0,713 * *$ & $0,802 * *$ & $0,513 * *$ & $-0,510 * *$ & $-0,386^{*}$ & $-0,436^{*}$ \\
\hline 7LSm23 & $0,724 * *$ & $0,508 * *$ & 0,290 & $-0,092$ & $-0,401^{*}$ & $-0,249$ \\
\hline 7LSm24 & $0,828 * *$ & $0,774 * *$ & $0,368^{*}$ & 0,099 & $-0,080$ & 0,215 \\
\hline 7LSm25 & $0,712 * *$ & $0,640 * *$ & 0,106 & $-0,108$ & 0,013 & $-0,240$ \\
\hline 7LSm26 & $0,868 * *$ & $0,834 * *$ & $0,544 * *$ & 0,135 & 0,211 & 0,017 \\
\hline 7LSm27 & $0,648 * *$ & $0,780 * *$ & 0,233 & $-0,052$ & 0,221 & $-0,283$ \\
\hline 7LSm28 & 0,087 & 0,713 ** & $-0,370^{*}$ & 0,287 & $-0,015$ & 0,034 \\
\hline 7LSm29 & $0,640 * *$ & $0,552 * *$ & $-0,129$ & $-0,227$ & $-0,340$ & $-0,010$ \\
\hline 7LSm30 & $0,745^{* *}$ & $0,716^{* *}$ & 0,345 & 0,318 & 0,136 & 0,101 \\
\hline
\end{tabular}

$*$ - correlation significant at $\mathrm{p} \leq 0.05$

** - correlation significant at $\mathrm{p} \leq 0.01$ 
Table 3.

Number of somaclonal families with different level of resistance to powdery mildew

\begin{tabular}{|c|c|c|c|c|c|}
\hline $\begin{array}{c}\text { Infection } \\
\text { rate }\end{array}$ & $\mathbf{5}$ & $\mathbf{6}$ & $\mathbf{7}$ & $\mathbf{8}$ & $\mathbf{9}$ \\
\hline $\mathbf{0}$ & 30 & 29 & 20 & 15 & 15 \\
\hline $\mathbf{1}$ & 0 & 1 & 9 & 10 & 10 \\
\hline $\mathbf{2}$ & 0 & 0 & 1 & 5 & 5 \\
\hline $\mathbf{3}$ & 0 & 0 & 0 & 0 & 0 \\
\hline $\mathbf{4}$ & 0 & 0 & 0 & 0 & 0 \\
\hline
\end{tabular}

\section{Acknowledgements}

Part of this work was financially supported by ESF project „Support for the implementation of doctoral studies at Daugavpils University" (Nr.2009/0140/1DP/1.1.2.1.2/09/IPIA/VIAA/ 015).

\section{References}

1. Lukaszewicz M., Szopa J., Krasowska A. Susceptibility of lipids from different flax cultivars to peroxidation and its lowering by added antioxidants. Food Chemistry, 2004, 88, p. 225-231.

2. Rashal I., Stramkale V., Conservation and use of the Latvian flax genetic resources. Proceedings of the Symposium "Bast Fibrous Plants Today and Tomorrow. Breeding, Molecular Biology and Biotechnology beyond 21th century", 28-30 September 1998, St. Petersburg, Russia. Natural Fibres, iss. 2, 1998, p. 56-58.

3. Grauda D., Stramkale V., Rašals I. Evaluation of Latvian flax varieties and hybrids. Proceedings in Agronomy, 2004, No. 6, p. 159-165.

4. Karp A. On the current understanding of somaclonal variation. In: Oxford Surveys of Plant Molecular and Cell Biology. B.J. Miflin (eds.), 1991, 7, p. 1-58

5. Vázquez A.M. Insight into somaclonal variation. Plant Biosystems, 2001, 135, iss.1, p.57-62

6. Bednarek P., Orłowska R., Koebner R., Zimny J. Quantification of the tissue-culture induced variation in barley (Hordeum vulgare L.). BMC Plant Biol., 2007, 7, p.10.

7. Ahloowalia B.S. Plant regeneration from embryo-callus culture in barley. Euphytica, 1987, 36, p. 659-665.

8. Choo T.M., Li J., Ho K.M., Kong D., Narisimhalu P. Somaclonal variation in Leger barley. Proceedings of the SABRAO International Symposium on the Impact of Biological Research on Agricultural Productivity, SABRAO, 1992, p. 163-174.

9. Karp A. Origins, causes and uses of variation in plant tissue cultures. In: Plant cell and tissue culture. I.K. Vasil, T.A Thorpe (eds.), Kluwer Academic Publishers, Dordrecht, 1994, p. 139-151.

10. Bregitzer P., Poulson M. Agronomic performance of barley lines derived from tissue culture. Crop Sci., 1995, 35, p.1144-1148.

11. Larkin, P.J.; Scowcroft, W.R. Somaclonal variation - a novel source of variability from cell culture for plant improvement. Theoretical Applied Genetics, 1981, 60, p. 197-214.

12. Leike, H. Methoden der Gewebekultur zur Beschleunigung des Zuchtfortschrittes. Tagungoberichts Akademie Landwirtschaft - Wissenschaft., 1985, 237, S. 19-33.

13. Poliakov, A.V. Biotechnology in flax Breeding. Tver, Russia, Format 2000, p. 84 (in Russian).

14. Grauda D., Mikelsone A., Rashals I. Use of antioxidants for enhancing flax multiplication rate in tissue culture, 2009, Acta Horticulture, Nr. 812, pp. 147-151. 